\title{
Deconstructing the Role of Storytelling in The Preservation of Indigenous Nigerian Traditions
}

\author{
Silk Ugwu Ogbu, PhD \\ School of Media and Communication, \\ Pan Atlantic University, KM 52 Lekki-Epe Expressway, \\ Ibeju-Lekki, Lagos-Nigeria
}

\begin{abstract}
Since the advent of Colonialism, a real concern has been and remains the struggle to hold on to indigenous traditions and cultural identities in Nigeria and across most of Africa in the face of the crusading influence of westernization. In the view of many Afrocentric pundits, it has become imperative that decisive measures need to be taken to reverse the tide of the rapidly deteriorating cultural identity of neo-colonial African societies. These measures are especially needed in the light of the rise in criminal behavior and general moral decadence among the youths which are said to be as a result of a crisis in cultural values. This paper draws on existing works in an attempt to depict the role of cultural markers and in particular, storytelling as a tool that can be wielded towards the preservation of the indigenous Nigerian cultures. The paper specifically argues that storytelling provides a solid basis for raising culturally adjusted individuals and inculcating values or norms that can foster decency, honesty, integrity and creativity in the minds of the young and future generations of Nigerians.
\end{abstract}

Keywords: Storytelling, tradition, culture, communication, folktales, cultural preservation

\section{INTRODUCTION}

Nigeria is a country blessed with a rich cultural heritage; with a myriad of indigenous languages and ethnicities that provide the fulcrum of its cultural identity. Globalization and modern media development has however put these identities in danger of being annihilated especially in the Eastern part of the country (Duruaku, 2015). Words, expressions and traditions are gradually ebbing away amidst the constant infiltration and dominance of the western world through changes in media consumption habits (Finnegan, 1970, Okwechime, 2004). In times past, the veritable vehicle for shaping morals, preserving historical achievements and the crucial part of instruction was through oral traditions and storytelling. Today, paradigms have shifted and gravitated towards modern proclivities. This poses a very real threat to the preservation of indigenous tradition for Nigeria as a nation.

No doubt, the country has faced a lot of challenges which has caused many scholars to introspect or investigate the origin of the changes to the fabric of our morality and indeed our own humanity. Societal ills have been on the increase as morals and morality continues to putrefy with the advent of each new generation. Crime rate has been on the incline and have caused us to wonder at the possibility of these issues coming at the heels of a broken moral compass (Ukoji \& Okolie-Osemene, 2016).

Certain questions arise: are there certain cultural cues or traditions we lose with the passing of each 'iroko' tree in our society? Has modern civilization and the influences of western culture changed our perspectives? Or is the problem with how we are able to teach and communicate to our children (means and methods), the values we hold dear and that are sacrosanct? 
This paper seeks to draw attention to our debilitating cultural identity and seeks ways to develop and harness it. It ponders the extent to which the use of cultural markers, especially oral traditions in instruction and tutelage of the younger generation can be vital to the preservation of cultural identities and traditions. In the beginning, many historians and schools of thought did not bother to study pre-colonial African history because most African societies had no written representation of historical events and traditions. Most accounts of historic legends, heroes and heroines are to this day recounted as myths (King, 2012). This is why oral tradition is at the very heart of African culture as a whole. Within that context, folklore, myths, legends and narratives are enshrined through interpretations of dance, songs, proverbs, riddles and religious practices. Prior to the advent of written materials as tools of historical/cultural preservation, oral traditions were the most prevalent forms of transmitting culture and tradition from one generation to another. According to Amadou Hampâté Bâ, a prolific Malian writer who worked at UNESCO in 1960, in Africa, whenever an old man dies, it was as painful and as irreplaceable as the incineration of an entire library, as most ancient tales and myths were never written but transmitted through generations via oral traditions. Thus:

"The people of Black race, as they are not peoples with a tradition of written literature, have developed the art of speech in a most special manner. While it is not written, their literature is not less beautiful. How many poems, epics, historic and chivalrous narratives, didactic tales, myths and legends of egregious literary style have so been transmitted through centuries, carried by the prodigious memory of the men with oral traditions, passionately in love with beautiful language and almost all poets." (Amadou Hampâté Bâ in (Kirshenblatt-Gimblett, 2004)

The Griots of Senegal were one of the most popular and oldest recorded media of preserving the oral traditions in West Africa as they were recognized as custodians of tradition. This highly respected profession was usually handed down from generation to generation ensuring that Kings, Queens and Princes and Princesses were educated and equipped for leadership. This serves to lend credence to the idea that beyond the entertainment advantage to storytelling, oral literature serves as a means of educating and instructing as well as entrenching indigenous norms in many civil societies (Achebe, 1975).

\section{Understanding Storytelling}

A story is understood to be a primary source of oral tradition because it communicates meaning, principles, standards and various other expressions in oral societies (Achebe, 1988). It is therefore usually a derisive tool for forming expressions commonly used by the literary world of African writers in their works. In the same vein, oral African storytelling can be considered as participatory in nature in the sense that it is usually designed through the use of songs and dance to engage the audience. This in itself encourages instruction and learning in traditional indigenous upbringing of a child, thereby awakening passively, a cultural consciousness crucial to cultural assimilation (Verbina, 2014). In the Nigerian context, storytelling is a means of recording and conveying emotions and responses of experiences and events (Gbadegesin, 1984) with the purpose of educating the younger generations about traditions, morals, expectations and culture. (Thiong'o,1986; Chinyowa, 2004; Utley, 2008). To tell a story is to recount past events to one or more listeners and weave an intriguing narrative in the imagination of listeners. According to Utley (2008), when folktales are analyzed and assimilated, it teaches them morals and provides them with a sense of identity as well as helps them to learn valuable life lessons (Matateyou, 1997)

The practice of storytelling is a participatory experience geared towards transmitting meanings in a bid to impart pedagogical or didactic lessons (Conference, 2016). In Nigeria and in many parts of Africa, after a hard day's work villagers would gather at the village square at 
night time under the moonlight and listen to stories told by the Sages (Achebe 1958; Thiong'o 1964). The participatory nature of the narration of the stories accompanied by singing, dancing, drumming and clapping makes it even more captivating and interesting to young ones (Vambe, 2001; Achebe 1958).

Stories are narratives that involve characters presented with challenges or crises that then proceed to make choices or decisions that influence outcomes either positively or negatively. Stories have a way of bringing principles and situations to life and making them real in an involved manner (Bruner, 1986). It goes beyond depicting instances, but venture further to elicit sympathy or emotion such that the engaged audience connects to the characters in a real and tangible manner (Polichak \& Gerrig, 2002). A key objective of storytelling is to pass a message or teach a lesson and shape certain morals in the hearts and mind of the audience.

In learning, Stories can play a vital role in shaping the consciousness of students through vehicles such as; holding attention of participants, engaging in subject matter discussions, igniting subject interest, solving puzzles created in scenarios narrated (case studies) and diffusing participant/student anxiety. Studies indicate that storytelling serves to create a relaxed and receptive atmosphere for information processing, analysis of subject matter which helps in the comprehension process. It also provides practical examples that aid in resolving conflicts and aid in learning that transcends the formal classroom experience but serve to hone listening skills, learning aptitude and appetite (Polichak \& Gerrig, 2002). Studies have shown that storytelling serves to develop imagination and creativity as well as cognition in child development (Anthony, 2014).

A good story often provides a basis upon which you can create an approach to resolving challenges that impede proper assimilation and understanding. Therefore, coherence is important to establish a connection between the situation depicted in the story, and its application in real life situations. They allow us to produce narratives that educate us about our history that transforms the fate of our future. The opportunity to learn from antecedents presents a learning curve that allows the transference of knowledge that fosters the preservation of our history, culture and tradition through generations. In this light, storytelling on its own can be understood to be a tradition in itself that contains a lesson to be learned, that inspires and direct our civilization on the path to greatness(Fisher, 1985). Through the valiant actions of characters depicted, stories demonstrate that greatness is not a derivative of background but a deliberate choice to make the right decision in spite of the odds that present themselves. In Storytelling, the engagement between the storyteller and the audience is both personal and active in the sense that communication is done both verbally and non-verbally. Cues such as language style, eye contact, facial expression and gestures serve to buttress the verbal narrative and bring stories to life in a tangible manner.

\section{Tradition as a Vehicle of Cultural Transmission}

Tradition can be viewed within moral and political contexts however, the interest in this work lies primarily within the socio-cultural context. According to Hobsbawm \& Ranger (2000), tradition is generally understood to mean "a set of practices normally governed by overtly or tacitly accepted rules and of a ritual or symbolic nature, which seek to inculcate certain values and norms of behavior by repetition, which automatically implies continuity with the past". It includes concepts of structure and paradigm which attempts to outline how we ought to process social framework in reference to thought, action and reaction as well as practices and responses to changes in our environment (Bevir, 2014). 
For the renowned writer George Orwell (1984), the one who controls the past, controls the future. This means that our understanding of our history, culture and norms shapes our outlook and determines our responses and reactions to challenges and situations we face in the present (Feyisetan, 2011) which in turn, determines the seeds we reap in the future. This fact is underscored in the many years of study, expedition and excavation devoted by anthropologists, archaeologists and historians alike who seek to understand human behavior and tell stories of the past through the gathering of evidence that predates civilization itself. This is with the knowledge that a people's culture and tradition is at the nucleus of its civilization and survival as well as constitutes the identity of any people (Kukah, 2007)

In spite of the barriers which have prevented the full understanding and appreciation of the African culture by the western world, the traditional African culture plays a vital role in the development of African intellectualism. Nwaorgu, (2010) posits that a people's perception of life and its experiences can align with their cultural experience which constitutes their beliefs or theories as well as cues that make up a coherent system or process that are the guidelines for their existence and co-existence. Many academics opine that the key to resolve contemporary challenges or issues that arise in fields of endeavor lie in salvaging and reinvigorating indigenous traditional systems that have been lost, forgotten or eroded since the age of colonialism (Sogolo, 1993; Otubanjo, 1989; Ojukwu \& Ezenandu, 2012). These schools of thought posit that the imposition of the colonialist agenda aggressively and viciously upset the balance that was the core of the African tradition and therefore a large part of the African identity was lost irretrievably.

Thus, in the light of the understanding of this challenge, it is pertinent to rediscover ways to begin the reclamation process of the African identity which can only be achieved through the practice of tradition and value systems indigenous to the continent. Some believe that a call for a reversal to the traditional way of life may indeed be an exercise in retrogression because, this approach may leave the modern-day African society ill equipped or prepared for topical challenges (Ciaffa, 2008; Hountondji, 1996). However, the issue must be approached with the knowledge that modernity may not necessarily be bad and that a civilization can only develop and grow if traditions are enriched. Another school of thought may provide a different alternative. That is to say that modernity must not necessarily be a herald of doom for the African tradition (they must not be mutually exclusive) but that both phenomena can be applied together to produce a more enriched cultural heritage that can be even more enduring, and with far reaching benefits for the future. The attention however that this paper wants to draw forward is in the application and approach to the use of modern facilities to enrich and foster traditional preservation.

On the one hand, modern culture connotes a reference to constituents of contemporary societies, cues, languages, norms, etc. which are a significant departure from the previously applicable but which are currently obtainable while on the other hand, tradition underscores a set of precepts seasoned through time, which have endured through generations and have come to embody the indigenous identity of a community or society.

The debate between the ideologies of modernization and traditionalism have been present in intellectual discourse of civilization for centuries however, there have been no definitive conclusions drawn entirely in favor or against either phenomena. Modernists argue that modernity has been the sole propeller of urbanization and development and view traditionalism as an archaic practice (Hameso, 1997; Ikpi \& Olayemi 1997) 
However, with modernism came the wistful realization that certain traditional values and aspects of civilization had begun to fade into extinction. Elements like handmade crafts (basketry, pottery, etc), folklore ,art, etc became museumized practices and tradition began to be perceived as a reservoir of history from which nuggets of rich wisdom and understanding could be tapped that were relevant to be applied even to modern situations and challenges (Horner , 1990). Traditionalism began to be understood as the fount of meaning and the well spring from which modernism draws its potency and richness.

\section{Storytelling and Tradition: A Symbiotic Relationship}

Indigenously, records of ancient written traditions do not exist in Nigeria and so what understanding we do have of traditions, cultural codes, value systems and tenets for preserving balance of social order in the Nigerian context are passed from generation to generation in oral form (Achebe, 1958; Chinyowa, 2001; Vambe, 2001). There was no written language, yet stories of great historical exploits and mythical creations were kept alive (Thiong'o, 1982).

Therefore, the practice of storytelling is meant not only for entertainment purposes, but to inculcate moral lessons about everyday challenges, and participation assists in ensuring that this traditional cultural education serves to crystallize a child's formation (Thiong'o, 1986; Utley, 2008; Achebe, 1958; Thiong'o, 1965; Sheppard, 2009).

In the words of Chinua Achebe

"..It is only the story that can continue beyond the war and the warrior. It is the story that outlives the sound of war-drums and the exploits of brave fighters. It is the story ...that saves our progeny (off-spring) from blundering like blind beggars into the spikes of the cactus fence. The story is our escort; without it, we are blind. Does the blind man own his escort? No, neither do we, the story; rather it is the story that owns us and directs us." (Achebe, 1987)

Chinyowa (2001) posits that African storytelling is a tool that sharpens the mind, shapes our behavior, harnesses our emotions and strengthens our propensity for creativity and imagination.

\section{THEORETICAL FRAMEWORK}

A theory that aptly provides the framework which encapsulates this work is known as Vygotsky's socio-cultural theory of human learning. This theory posits that a child's cognitive ability (knowledge or understanding) is a function of his/her culture or society and is therefore a social process. According to Vygotsky, learning occurs first through social interaction, then within the individuals mind. This means that for every learning function that a person experiences, a cultural development occurs on a social level first, then on a personal level. What this elaborates is that you draw your own meanings and deductions after having picked up the meanings through associating with others. Learning is therefore formed initially through interacting with others (parents, teachers, peers, etc), then subsequently chewed upon and understood within the child/person's mind which then reflects on the outward and even in decision making. This applies to cognitive functions such as logical memory, concept development, etc. (Vygotsky, 1978). The theory explains that for youths to imbibe and sustain their cultural identity or traditions, these traditions must be taught through a process of social learning. This means that first, traditions through the means of storytelling (music, dance and folktales) can be assimilated first by listening and participating via storytellers or among social peers, then finally digested while ruminating or reflecting personally or individually. This way, 
the cultural identities are completely assimilated and indoctrinated into the hearts and minds of individuals who can then transmit it to an even younger generation in turn.

Another theory of interest in this work is the theory of the narrative paradigm which was propounded by Walter Fischer. His theory posits that all human beings are recipients and originators of stories which are narratives in themselves (Fisher, 1985). He asserts that narratives that resonate with people are usually stories shaped by a series of events, historical or cultural markers. Storytelling is without a doubt a veritable tool which oral societies used in conveying meaning and the narrative paradigm corroborates that a story may be used to convey meanings that will resonate better with an audience and this in turn can open a channel that can allow history and traditions to be passed from generation to generation for preservation purposes.

\section{Folktales}

In Hove (1997), the more commonly used forms of storytelling were the folktales or 'trickster stories'. These trickster stories are considered as the use of animal characters imbued with human personalities to aid in better relating to the stories. They portray courage and strength in some animals and cunning and avarice or greed in others (Achebe, 1958; Thiong'o 1982). These stories are developed with the purpose of teaching a moral lesson to the intended audience. A classic example to consider is the Yoruba folktale titled: "Pride Comes with a Great Fall", the deer claimed to be the fastest runner in the entire animal kingdom and challenged any other animal to contest with him for a twenty-six mile race. However, the tortoise depicted as the more cunning character, ensured that thirteen of his family members were positioned at every other mile. Initially, the deer exulted in his victory at speeding past the Tortoise at the first mile, but was chagrined that the Tortoise seemed to mock him two miles ahead and so he ran even faster pushing himself further beyond even his own physical limits. The deer eventually died of sheer exhaustion two miles before the finish line. The moral lesson to be learned from this story is that arrogance can have dire repercussions. Trickster stories like the above teach that the race is not always won by the quick or sure-footed, the brave or the strong, but sometimes, by the cunning and intelligent. The goal is to help the audience appreciate the wit and ingenuity that leads the animal trickster to overcome one victory after another. (Mandela, 2002) The hare is the popular animal trickster among the Jukun and Angass people of Nigeria (Taraba, Benue, Plateau and Nasarawa States) while the tortoise is more favored among the Yoruba (Ijapa), Edo (Ikaki), and Igbo (Mbeku) trickster stories.

\section{Imperatives of Storytelling as a Gateway to Cultural Preservation}

From this work, we can deduce that proper instruction and development of the younger generation and old alike would be incomplete without ensuring their understanding and assimilation of indigenous cultural values which are enshrined in folklore of indigenous Nigerian peoples particularly in folktales. It is important that we encourage the younger generation to develop an interest in and an affinity for indigenous culture and tradition. Who we become as a people may very well depend on our ability to inculcate these core values into the hearts and minds of the newer generations. According to Duruaku (2015) an effective way to ensure the transmission of indigenous tradition is to maintain the practice of folklore. This is to ensure that values which define our cultural identity ensconced in proverbs, stories, music and dance are preserved in their original form.

It may also be salient to integrate the participation of schools and learning institutions in this process as they embody one of the major agents of socialization. This will force the recognition of the promotion of indigenous cultures into the societal system. Beyond adopting storytelling as a part of our educational curriculum, modern media channels can be used in the 
transmission of these stories and folktales to a wider audience. Chimamanda Adichie, Chinua Achebe and indeed, many other prolific award-winning Nigerian authors of repute have set a precedence in the prose genre. However, the area of folktales adaptation and dissemination is an area that has hardly been fully explored. Folktales have a unique characteristic of succinctness, versatility and agelessness which has the potential of appealing to an audience with an ever-diminishing attention span.

An opportunity presents in using modern trends and tools as vehicles for reaching the intended audience. It may be of value to engage with the younger audience on the platforms in which they are accustomed to enjoying in terms of media consumption. The social media for instance has become the hub of content for most media consumers both young and old. If we have any chance of stemming the rising tide of fading cultures around the world and in indeed, in our country, a deliberate effort has to be made in the adapting of indigenous folktales to movies, series, theatre and other electronic forms including video, audio, animation (cartoon) and video games. In addition, there exists an option of developing folktales in form of comics that the younger generation can read and enjoy as well as videos and animations which may prove useful in inculcating the values we desperately need our younger generation to imbibe.

\section{CONCLUSION}

In this era of digitalized media, storytelling as means of preserving indigenous cultures in Nigeria may be difficult for many to understand or accept. Overtime, this rich communication apparatus has been jettisoned for the instant gratifications of the fast moving motion pictures and the make-believe fantasies that were sold to us with the broadcast media in forms of television or video content. As we were busy consuming the content of these foreign programs in the search for entertainment and short trills, many failed to notice that we were also exposing ourselves and our younger generations to the values and cultures of the west as projected in their movies. Today, our children dress like them, talk like them, act like them and even grow up aspiring to be like the characters in the western movies they watch. This is a serious problem. We are beginning to see an erosion of our core virtues and values as Africans because we abandoned our traditional method of transmitting our cultures through storytelling. This paper believes that it is possible to resurrect the art of storytelling by codifying the myths and rich historical antecedents of Nigeria societies into oral instruments that can be transmitted to the younger generations using digitalized formats. It argues that in this culturally predatory world, Nigeria must seek not just to preserve its indigenous cultures but also to export them to other parts of the world, especially the western countries of Europe and America, where moral values are declining at an alarming rate.

\section{References}

Achebe, C. (1966). A Man of the People. London: Heinemann.

Achebe, C. (1975). An Image of Africa: Racism in Conrad's Heart of Darkness. Hopes and Impediments . Amherst, USA: University of Massachusetts.

Achebe, C. (1987). Anthills of the Savannah. London: Heinemann.

Anthony, M. (2014, April 10). Cognitive development in 6 - 7 year olds. Retrieved from scholastic.com: http://www.scholastic.com/parents/resources/article/cognitive

Asihene, E. (1997). Traditional Folk-Tales of Ghana. New York: Edwin Mellen Press.

Berry, J. (1991). The Afrocentric Idea. Philadelphia, USA: Temple University Press.

Bevir, M. (2014). On Tradition. HUMANITAS , 28-53.

Bishop, R. (1998). West African Folktales. Illinois: Northwestern University Press.

Bruner, J. (1986). Actual minds, possible worlds. Cambridge, MA: Harvard University Press. 
Cambridge University Press. (n.d.). Oral Tradition in the Criticism of African Literature. The Journal of Modern African Studies , 13(1): 107-119.

Carroll, K. K. (2008). Freeing ourselves from neo-colonial domination in research: A Mâori approach to creating knowledge. Qualitative Studies in Education , 11(2): 199-219.

Chinyowa, K. (2004). Shona storytelling \& the contemporary performing arts in Zimbabwe. Gweru, Zimbabwe: Mambo Press.

Ciaffa, J. A. (2008). Tradition and Modernity in postcolonial African philosophy. Humanitas .

Conference, P. o. (2016). 21st Century Tensions and Transformation in Africa. 21st Century Tensions and Transformation in Africa. Deakin University.

Courlander, H. (1996). A Treasury of African Folklore. New York: Marlowe and Company.

Dada, O. (1970). West African Folktales. Philadelphia: Dorrance and Company .

Duruaku, T. (2015). Animated graphic film for the rejuvenation of a fading culture: The case of an African oral heritage. African Journal of History and Culture , 7(6):123-132.

Egudu, R. N. (1981). Achebe and the Igbo Narrative Tradition. Research in African Literatures , 12(1) 43-54.

Feyisetan, G. (2011). Should we be Heroes or Saints, whether we are victims or victors of modernity? Don Bosco.

Finnegan, R. (1970). Oral Literature in Africa. Nairobi: Oxford University Press.

Fisher, W. R. (1985). The Narrative Paradigm: In the Beginning. Journal of Communication , 74-89.

Fisher, W. (1985). The Narrative Paradigm: In the Beginning. Journal of Communication , 35: 74-89.

Folami, \& Olaiya. (2016). Gender, storytelling and peace construction in a divided society: A case study of the Ife/Modakeke conflict. Cogent Social Sciences .

Foley, J. M. (1986). Oral Tradition in Literature. Columbia : U of Missouri P, 1986. Columbia: U of Missouri Press. Gbadegesin, S. (1984). Destiny, personality and the ultimate reality of human existence. Ultimate Reality and Meaning , 7(3): 173-188.

Green, M. C. (2004). Storytelling in Teaching . Observer: The Association for Psychological Science .

Haley, G. E. (1970). A Story, A Story. New York: Connecticut Publishers.

Hameso, S. Y. (1997). Ethnicity in Africa: Toward A positive Approach. London: Oxford University Press.

Hobsbawm, E., \& Ranger, T. (2000). Invention of Tradition. London: Cambridge University Press.

Hock, R. R. (2002). Forty studies that changed psychology: Explorations into the history of psychological research . Upper Saddle River, NJ: Prentice-Hal.

Homer, A. E. (1990). The Assumption of Tradition: Creating, Collecting and Conserving Cultural Artifacts in the Cameroon Grassfields (West Africa). Berkeley: University of California.

Hountondji, P. (1996). African philosophy: Myth and Reality. Blowmington: Indiana University Press.

Ikpi, A. E., \& Olayemi, J. K. (1997). Governance and Development in West Africa: perspectives for the 21st Century. African Rural Social Science Research Networks .

Kirshenblatt-Gimblett, B. (2004). Intangible heritage as metacultural production. Museum International , 221222:52-65.

Kouyate, D. (1989). The role of griot. In L. Goss, \& M. E. Barnes, Talk that talk: An anthology of African-American storytelling ). (pp. 179-181). New York, USA: Simon \& Schuste.

Kukah, M. H. (2007). Religion, culture and the politics of Development Centre for Black and African. Lagos: Centre for Black and African Arts and Culture (CBAAC).

Lindfors, B. (1973). Folklore in Nigerian Literature. New York: Africana Publishing.

Mandela, N. (2002). Favorite African Folktales. New York : W.W. Norton and Company.

Mandela, N. (2002). Favorite African Folktales: This is a collection of traditional folktales from different regions of Africa. New York, USA: W.W. Norton and Company.

Matateyou, E. (1997). An Anthology of Myths, Legends and Folktales. New York: Edwin Mellen Press.

Matateyou, E. (1997.). An Anthology of Myths, Legends and Folktales. New York: Edwin Mellen Press. 
McDermott, G. (1972). Anansi the Spider. New York: Henry Holt and Company.

Meyer, R. G. (2003). Teaching tips : Case studies in abnormal behavior. Boston: Allyn and Bacon.

Niane, S. D. (1989). An Epic of Old Mali. Hong Kong: Longman Group.

Nwaorgu, O. G. (2010). African philosophy and Africa's Predicament. Ibadan: Book Wright.

Ojukwu, C. C., \& Ezenandu, P. E. (2012). A Paradigm Shift from Tradition to Modernity in Nollywood's Projection of African Narratives. Global Journal of HUMAN SOCIAL SCIENCE , 21-26.

Okwechime, E. O. (2004). Igbo oral literature and globalization- the missing link. Journal of Nigerian Language and Culture (JONLAC) , 6(2):111-117.

Orwell, G. (1949). Nineteen eighty Four. Secker.

Otubanjo, F. (1989). Themes in African Traditional political thought. In J. A. Ayoade, \& A. A. Agbaje, African Traditional Political Thought and Institutions. Lagos: Centre for Blak and African Arts and Civilization (CBAAC) .

Owomoyela, O. (1997). Yoruba Trickster Tales. London: University of Nebraska Press.

Polichak, J., \& Gerrig, R. (2002). Get up and win: Participatory responses to narrative. In M. C. Green, J. J. Strange, \& T. C. Brock, Narrative impact: Social and cognitive foundations (pp. 71-96). Mahwah, NJ: Erlbaum.

Sheppard, T. (2009). Traditional Storytelling in Africa. Retrieved from Tim Sheppard's Storytelling Resources for Storytellers: http://www.timsheppard.co.uk/story/dir/traditions/africa.html

Sogolo, G. (1993). Foundations of African philosophy. A definitive Analaysis of conceptual issues in african thought. Ibadan: Ibadan University press.

Thiong'o, N. w. (1986). Decolonising the Mind: The Politics of Language in African Literature. Nairobi, Kenya: East African educational Publishers.

Thiong'o, N. w. (1964). Weep Not, Child. New York, USA: Penguin Group.

Ukoji, V. N., \& Okolie-Osemene, J. (2016). A Study of Crime Reporting in Nigeria. Nigeriawatch.org.

Utley, 0. (2008, January 9). Keeping the Tradition of African Storytelling Alive. Retrieved May 1, 2017, from Yale National Initiative: http://teachers.yale.edu/curriculum/viewer/initiative_09.01.08_u\#h1num-10

Vambe, M. T. (2001). Orality and Cultural Indentities in Zimbabwe. Retrieved from africanbookscollective: http://www.africanbookscollective.com/books/orality-and-cultural-indentities-inzimbabwe\#sthash.S8POBfBM.dpuf

Verbina, H. A. (2014). Tradition of oral literature in the works of Chinua Achebe-An insight. Kafla Intercontinental . Vygotsky, L. (1978). Mind in Society: Development of Higher Psychological Processes. 